\title{
Particular Vibration Spectrum of Antimony Trichloride Caused by Bond Fluctuation
}

\author{
Hans Friedewold and Wolfgang Brockner \\ Institute of Inorganic and Analytical Chemistry, Technical University of Clausthal, \\ Clausthal-Zellerfeld, FRG
}

Z. Naturforsch. 46a, 595-598 (1991); received April 27, 1991

Vibration spectra of solid and molten antimony trichloride were recorded. In the solid state, vibration frequencies in addition to those of the $\mathrm{SbCl}_{3}$ molecules with their $\mathrm{C}_{3 v}$ symmetry indicate bond fluctuations according to $2 \mathrm{SbCl}_{3} \rightleftharpoons \mathrm{Sb}^{+}+\mathrm{SbCl}_{6}^{-}$.

Key words: $\mathrm{SbCl}_{3}$, Vibration spectrum, Bond fluctuation, Electron transfer.

\section{Introduction}

In the past, antimony trichloride has extensively been investigated by structure sensitive methods, especially by vibration spectroscopy $[1-8] . \mathrm{SbCl}_{3}$ crystallizes in the space group Pnma $\left(\mathrm{D}_{2 \mathrm{~h}}^{16}\right)$, and it is isotopic with several trihalides of Group V elements like $\mathrm{NCl}_{3}$, $\mathrm{PCl}_{3}, \mathrm{PBr}_{3}, \mathrm{AsCl}_{3}, \beta-\mathrm{SbBr}_{3}$ and $\mathrm{BiCl}_{3}$.

In the solid state, the vibration spectra of these compounds differ considerable from their melt and gas spectra. The last ones can be explained by the $\mathrm{C}_{3 \mathrm{v}}$ symmetry of the $\mathrm{AB}_{3}$ molecule.

The more complex vibration spectra of the solids are mostly caused by intermolecular interactions. Especially the Raman spectra of the phosphorus and arsenic trihalides exhibit many additional bands [9-10] while $\mathrm{SbCl}_{3}, \mathrm{SbBr}_{3}, \mathrm{BiCl}_{3}$ and $\mathrm{BiBr}_{3}$ show a simpler splitting pattern [3-8, 11]. For $\mathrm{PBr}_{3}$ below $200 \mathrm{~K}$ ten Raman active deformation and stretching frequencies were observed while for $\mathrm{SbCl}_{3}$ below $340 \mathrm{~K}$ there are only seven Raman bands.

Obviously different interactions exist in these solids despite the same crystal structure. This has not been sufficiently considered in the cited investigations, so that a new discussion of the $\mathrm{SbCl}_{3}$ vibration spectrum is justified.

Reprint requests to Prof. Dr. W. Brockner, Institut für Anorganische und Analytische Chemie, Technische Universität Clausthal, Paul-Ernst-Straße 4, W-3392 Clausthal-Zellerfeld, FRG.

\section{Results}

The FIR spectra as well as the Raman spectrum of crystalline $\mathrm{SbCl}_{3}$ along with the Raman spectrum of a solidified melt sample of $\mathrm{SbCl}_{3}$ with $15.0 \mathrm{~mol} \% \mathrm{RbCl}$ are presented in Figure 1. Table 1 summarizes the observed frequencies $\left(\mathrm{cm}^{-1}\right)$ of solid $\mathrm{SbCl}_{3}$ and the $\mathrm{SbCl}_{3}-\mathrm{RbCl}$ mixture along with their intensities and literature data $[3,15]$. Especially the low temperature FIR spectrum of $\mathrm{SbCl}_{3}$ at $8 \mathrm{~K}$ demonstrates that it is much more complex than formerly assumed.

\section{Description of the Structure}

Based on data of Lindquist and Niggli [1] a section of the crystal structure of $\mathrm{SbCl}_{3}$ is sketched in Figure 2. The unit cell with space group Pnma consists of four molecular units. In Table 2 the numbers and distances of the $\mathrm{Sb}-\mathrm{Cl}$ coordiations are given. Therefore Lipka [2] proposed a 3-dimensional structure built up by bicapped-trigonal prisms, so that a coordination number 8 for antimony results (Figure 2).

In general, it is difficult to make predictions for real chemical bonds only on the basis of $\mathrm{X}$-ray structure data. So the $\mathrm{Sb}-\mathrm{Cl}$ coordinations with distances in the range of $345-400 \mathrm{pm}$ cannot be considered as distinct chemical bonds.

\section{Experimental}

Spectroscopically pure $\mathrm{SbCl}_{3}$ was prepared by the reaction of antinomy pentachloride and antimony according to

$$
3 \mathrm{SbCl}_{5}+2 \mathrm{Sb}=5 \mathrm{SbCl}_{3} .
$$

0932-0784 / $91 / 0700-0595 \$ 01.30 / 0$. - Please order a reprint rather than making your own copy. 


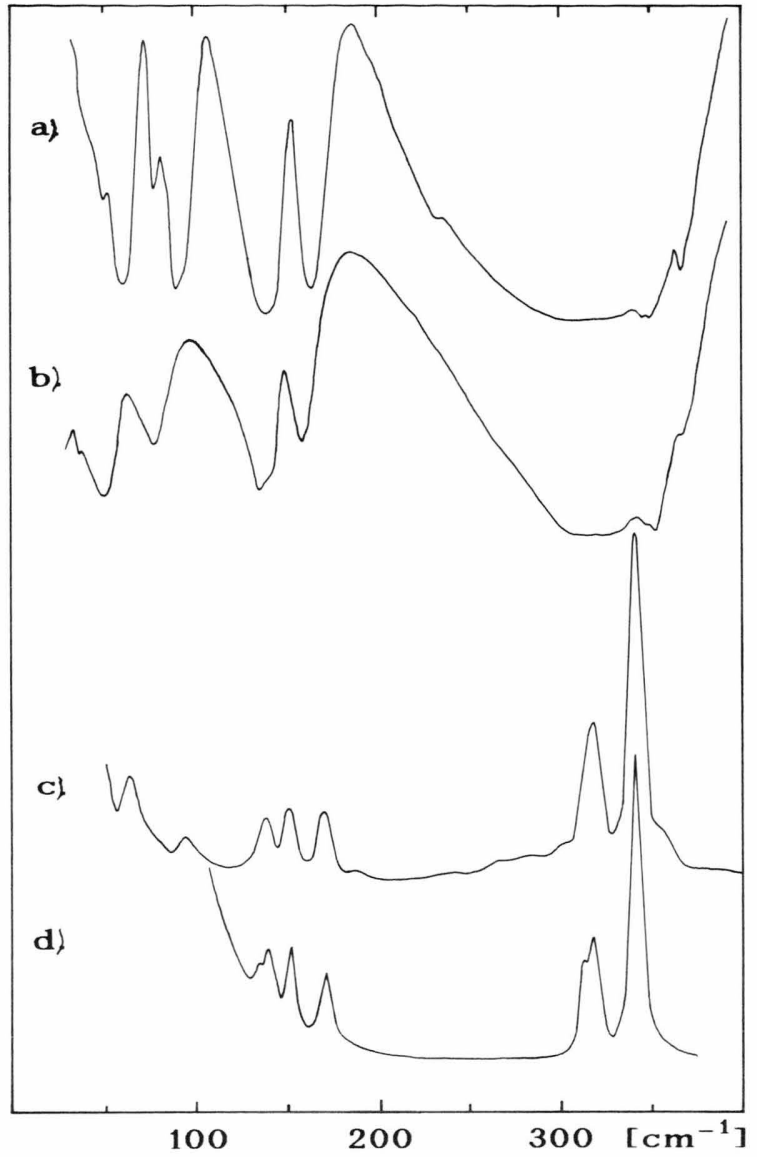

Fig. 1. Vibration spectra of antimony trichloride. a) Low temperature FIR spectrum ( $8 \mathrm{~K})$. b) Room temperature FIR spectrum. c) Raman spectrum of a solidified melt sample of $\mathrm{SbCl}_{3}$ with $15 \mathrm{~mol}_{\%} \mathrm{RbCl}$ (room temperature). d) Room temperature Raman spectrum.

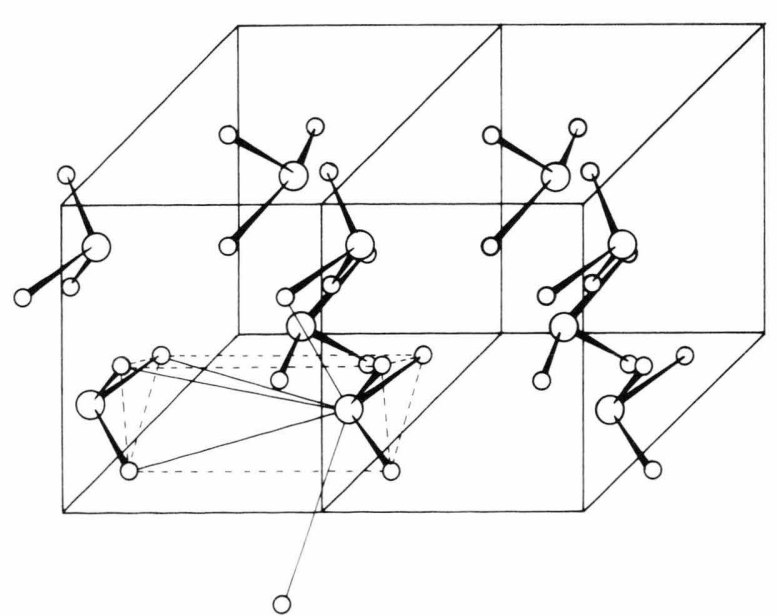

Fig. 2. Crystal structure of $\mathrm{SbCl}_{3}$ (Pnma) based on data of [2] with four $\mathrm{SbCl}_{3}$ molecules in the unit cell.
Table 1. Vibrational frequencies $\left(\mathrm{cm}^{-1}\right)$ of antimony trichloride with their intensities and literature data $[3,15]$ for comparison.

\begin{tabular}{|c|c|c|c|c|c|}
\hline $\mathrm{RE}(\mathrm{RT})$ & $\begin{array}{l}\mathrm{RE}(\mathrm{RT}) \\
+0.15 \mathrm{RbCl}\end{array}$ & RE [3] & FIR (RT) & FIR [15] & FIR $(8 \mathrm{~K})$ \\
\hline & & & $\begin{array}{l}35 \mathrm{~m} \\
45 \mathrm{msh} \\
47 \mathrm{vwsh} \\
50 \mathrm{~s} \\
67 \mathrm{vwsh} \\
78 \mathrm{~s}\end{array}$ & & $\left\{\begin{array}{l}50 \mathrm{w} \\
57 \mathrm{~s} \\
61 \mathrm{~s} \\
76 \mathrm{~m} \\
89 \mathrm{vs} \\
93 \mathrm{ssh}\end{array}\right.$ \\
\hline & & $94 \mathrm{~m}$ & 113 vwsh & & \\
\hline $135 \mathrm{msn}$ & & $133 \mathrm{~m}$ & $135 \mathrm{~s}$ & 128.1 & 137 vs \\
\hline $\begin{array}{l}139 \mathrm{~m} \\
151 \mathrm{~m}\end{array}$ & $\begin{array}{l}139 \mathrm{~m} \\
151 \mathrm{~m}\end{array}$ & $\begin{array}{l}138 \mathrm{~m} \\
150 \mathrm{~m}\end{array}$ & $141 \mathrm{~s}$ & & 142 vs \\
\hline & & & $159 \mathrm{~s}$ & 164.0 & $\begin{array}{l}160 \mathrm{~s} \\
163 \mathrm{~s}\end{array}$ \\
\hline $170 \mathrm{~m}$ & $169 \mathrm{~m}$ & $169 \mathrm{~m}$ & $\begin{array}{l}192 \text { vwsh } \\
308 \mathrm{~s}\end{array}$ & & $\begin{array}{l}189 \mathrm{wsh} \\
228 \mathrm{~m} \\
296 \mathrm{~s} \\
304 \mathrm{~s}\end{array}$ \\
\hline $\begin{array}{l}313 \mathrm{~s} \\
318 \mathrm{~s}\end{array}$ & $318 \mathrm{~s}$ & $\begin{array}{l}312 \mathrm{~s} \\
318 \mathrm{~s}\end{array}$ & $\begin{array}{l}324 \mathrm{~s} \\
330 \mathrm{~s}\end{array}$ & & $333 \mathrm{~s}$ \\
\hline 342 vs & 341 vs & 340 vs & $\begin{array}{l}348 \text { vs } \\
354 \text { vs } \\
363 \mathrm{wsh} \\
371 \mathrm{~m}\end{array}$ & $\begin{array}{l}356.1 \\
376.5\end{array}$ & $\begin{array}{l}346 \text { vs } \\
352 \text { vs } \\
363 \text { wsh } \\
369 \mathrm{~m}\end{array}$ \\
\hline
\end{tabular}

$\mathrm{s}=$ strong, $\mathrm{m}=$ medium, $\mathrm{w}=$ weak, $\mathrm{v}=$ very, $\mathrm{sh}=$ shoulder.

\begin{tabular}{lc}
\hline$N$ & SbCl distances \\
\hline 1 & 234 \\
2 & 237 \\
2 & 346 \\
1 & 361 \\
2 & 374 \\
\hline
\end{tabular}

Table 2. Number $(N)$ of $\mathrm{Sb}-\mathrm{Cl}$ coordinations and corresponding $\mathrm{Sb}-\mathrm{Cl}$ distances (pm) below $400 \mathrm{pm}$ (the sum of the van der Waals radii) for crystalline $\mathrm{SbCl}_{3}[2]$.

For further purification this product was destilled four times over antimony and zinc, respectively. All manipulations and operations were carried out in a dry argon atmosphere under extreme exclusion of air and humidity. In accordance with the literature value [12], the $\mathrm{SbCl}_{3}$ produced had a melting point of $346.35 \mathrm{~K}$.

The Raman spectra were recorded with a Coderg PH1 spectrometer and laser beam excitation (Krypton Ion Laser, Spectra Physics 165/01; 647.1 nm). The Raman scattering was observed perpendicular to the incident laser beam. The spectrometer and modified 


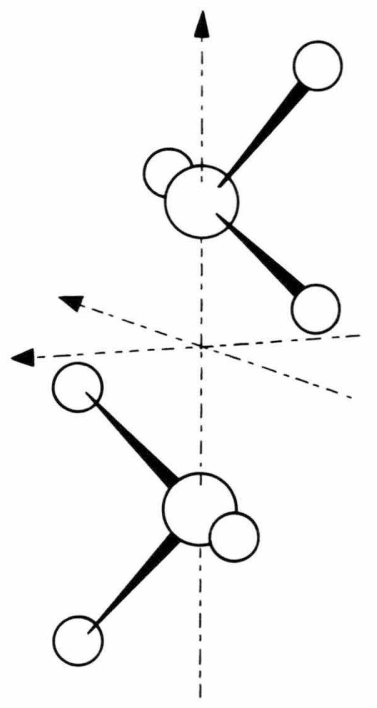

Fig. 3. Vibration spectroscopically relevant unit cell with two $\mathrm{SbCl}_{3}$ units and the factor group $\mathrm{C}_{2 \mathrm{~h}}$.

sample compartment have already been described [13, 14]. The room temperature far infrared (FIR) spectrum was recorded with a modified Beckman interferometer FS 720 interfaced to a Kontron KAP 1000 computer for acquiring and manipulating the data, and the low temperature FIR spectrum with a Bruker IFS 113 FT spectrometer.

\section{Discussion}

So far the interpretation of the $\mathrm{SbCl}_{3}$ vibration spectrum is based on factor group analyses with four $\mathrm{SbCl}_{3}$ molecules integrated in the unit cell [4]. The four fundamentals of the $\mathrm{SbCl}_{3}$ molecules $\left(2 \mathrm{~A}_{1}+2 \mathrm{E}\right)$ then split into 24 vibrations according to

$$
\begin{aligned}
\Gamma_{\mathrm{vib}}\left(\mathrm{D}_{2 \mathrm{~h}}\right)= & 4 \mathrm{~A}_{\mathrm{g}}(\mathrm{RE})+2 \mathrm{~B}_{1 \mathrm{~g}}(\mathrm{RE})+4 \mathrm{~B}_{2 \mathrm{~g}}(\mathrm{RE}) \\
& +2 \mathrm{~B}_{3 \mathrm{~g}}(\mathrm{RE})+2 \mathrm{~A}_{\mathrm{u}}+4 \mathrm{~B}_{1 \mathrm{u}}(\mathrm{IR}) \\
& +2 \mathrm{~B}_{2 \mathrm{u}}(\mathrm{IR})+4 \mathrm{~B}_{3 \mathrm{u}}(\mathrm{IR}) .
\end{aligned}
$$

Species in $\mathrm{A}_{\mathrm{u}}$ are inactive and the mutual exclusion rule is valid. Instead of the twelve Raman active deformations and stretchings expected only seven could be observed.

With an equalization of the crystallographic with the spectroscopic unit cell, 3-dimensional interactions are assumed which at least are so high that they deliver a contribution to the vibrational behavior. If one of these contributions exceeds the others significantly,
Table 3. Splitting schematic for crystalline $\mathrm{SbCl}_{3}$ and proposed assignment of the vibration frequencies $\left(\mathrm{cm}^{-1}\right)$.

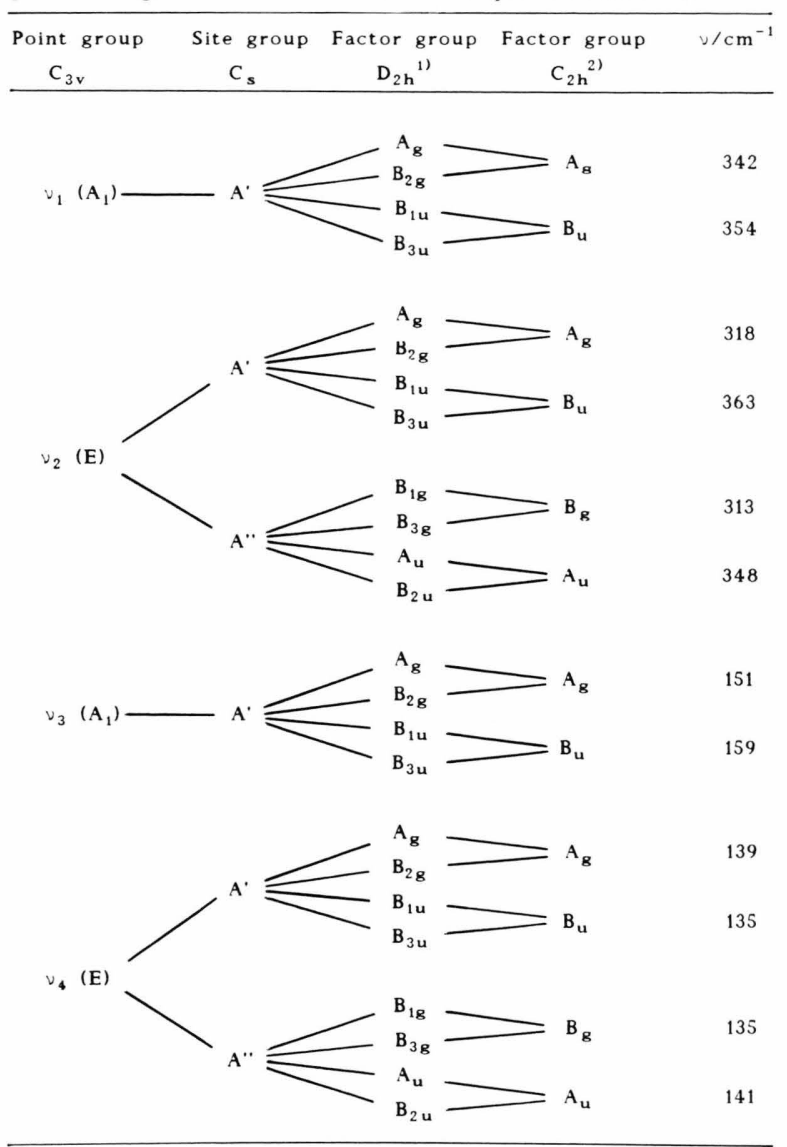

then vibrations move close together and cannot be separated any more, and a distinct assignment of the vibration modes is impossible.

In this case it is suitable and allowed to reduce the basic unit of a factor group analysis, that is to halve the crystallographic unit cell. As a result, the factor group $\mathrm{C}_{2 \mathrm{~h}}$ (Figure 3) is obtained. Thus, the $\mathrm{SbCl}_{3}$ structure may be imagined as a linear chain of $\mathrm{AB}_{3}$ molecules, and according to Table 2 only the intermolecular $\mathrm{Sb}-\mathrm{Cl}$ distances to $346 \mathrm{pm}$ are considered as interactions; therefore the coordination number of antimony is five.

A vibrational analysis with two $\mathrm{SbCl}_{3}$ molecules in the unit cell leads to the following result:

$\Gamma_{\text {vib }}\left(\mathrm{C}_{2 \mathrm{~h}}\right)=4 \mathrm{~A}_{\mathrm{g}}(\mathrm{RE})+2 \mathrm{~B}_{\mathrm{g}}(\mathrm{RE})+2 \mathrm{~A}_{\mathrm{u}}(\mathrm{IR})+4 \mathrm{~B}_{\mathrm{u}}(\mathrm{IR})$.

As expected, the number of the vibrations is halved, and the Raman spectrum should show three deformation as well as three stretching frequencies. 
In Table 3 the splitting schematic for the different models used and the assignment of the frequencies for the reduced spectroscopic unit cell are summarized and compared. These results demonstrate that the number of species in the deformation and stretching region must always have the same value independently of the ansatz chosen. This is contrary to the experimental Raman spectrum (Fig. 1d) where four deformation and three stretching vibrations are observed. Therefore the Raman band at $170 \mathrm{~cm}^{-1}$ in the $\mathrm{SbCl}_{3}$ Raman spectrum is not caused by the $\mathrm{SbCl}_{3}$ molecules and/or its intermolecular interactions in the lattice.

Obviously, small additions of alkali chloride disturb considerably the $\mathrm{SbCl}_{3}$ structure (cf. Fig. 1c; $\mathrm{SbCl}_{3}+15 \mathrm{~mol} \% \mathrm{RbCl}$ ). Here the Raman bands at 318 and $139 \mathrm{~cm}^{-1}$ are no more split. Nevertheless, the Raman vibration at $170 \mathrm{~cm}^{-1}$ remains with unchanged intensity.

In the $\mathrm{SbCl}_{3}$ crystal structure rapid electron transfer or bond fluctuations are imaginable, which will cause structural defects, and could be a possible reason for the existence of the Raman band at $170 \mathrm{~cm}^{-1}$. It is striking that the complex anion $\mathrm{SbCl}_{6}^{-}$shows a strong Raman deformation at $170 \mathrm{~cm}^{-1}\left(v_{5}\left(\mathrm{~F}_{2 \mathrm{~g}}\right)\right.$, too, which has been observed in several compounds of the type $\mathrm{Me}^{\mathrm{I}} \mathrm{Sb}^{\mathrm{V}} \mathrm{Cl}_{6}\left(\mathrm{Me}^{\mathrm{I}}=\mathrm{K}^{+}, \mathrm{Rb}^{+}, \mathrm{Cs}^{+}, \mathrm{NO}^{+}\right)[16-20]$ as well as in the mixed-valent type $\mathrm{Me}_{4}^{\mathrm{I}} \mathrm{Sb}^{\mathrm{III}} \mathrm{Cl}_{6} \mathrm{Sb}^{\mathrm{V}} \mathrm{Cl}_{6}$ [21-24]. Possibly $\mathrm{SbCl}_{6}^{-}$may originate by a rapid

[1] I. Lindquist and A. Niggli, J. Inorg. Nucl. Chem. 2, 345 (1956).

[2] A. Lipka, Acta Cryst. B 35, 3020 (1979).

[3] K. W. Fung, G. M. Begun, and G. Mamantov, Inorg. Chem. 12, 53 (1973).

[4] E. Chemouni, J. Inorg. Nucl. Chem. 33, 2317 (1971).

[5] A. T. Kozulin, Opt. Spektrosk. 32, 374 (1972).

[6] A. T. Kozulin, A. V. Gogolev, and N. I. Noskov, Opt. Spektrosk. 40, 518 (1976).

[7] M. Fontana, G. Maisano, P. Migliardo, C. Vasi, and F. Wanderlingh, Optica Acta 27, 1087 (1980).

[8] F. Aliotto, G. Maisano, N. Micali, P. Migliardo, C. Vasi, and F. Wanderlingh, J. Chem. Phys. 76, 3987 (1982).

[9] A. T. Kozulin, A. V. Gogolev, V. I. Karmanov, and V. A. Murtsovkin, Opt. Spektrosk. 34, 708 (1973).

[10] D. J. Stufkens, Rec. Trav. Chim. 89, 755 (1970).

[11] R. P. Oertel and R. A. Plane, Inorg. Chem. 8, 1188 (1969).

[12] G. J. Janz and R. P. T. Tomkins, Nonaqueous Electrolytes Handbook, Vol. II, Academic Press, New York London 1973.

[13] W. Bues, W. Brockner, and D. Grünewald, Spectrochim. Acta 28 A, 1519 (1972).

[14] H. A. Øye and W. Bues, Inorg. Nucl. Chem. Letters 8, 31 (1972). electron or bond fluctuation in the $\mathrm{SbCl}_{3}$ crystal structure according to a more formal equilibrium reaction

$$
2 \mathrm{SbCl}_{3} \rightleftharpoons \mathrm{Sb}^{+}+\mathrm{SbCl}_{6}^{-} .
$$

The $v_{1}\left(\mathrm{~A}_{\mathrm{g}}\right)$ Raman stretching frequency of the $\mathrm{SbCl}_{6}^{-}$ anion at $340 \mathrm{~cm}^{-1}$ could be covered by an $\mathrm{SbCl}_{3}$ fundamental. Normally the $v_{2}\left(\mathrm{E}_{\mathrm{g}}\right)$ Raman band of the octahedral $\mathrm{SbCl}_{6}^{-}$at $284 \mathrm{~cm}^{-1}$ is very weak, so that the lack of such a band in the $\mathrm{SbCl}_{3}$ spectrum could be explained.

As a further hint for the existence of $\mathrm{SbCl}_{6}^{-}$in solid $\mathrm{SbCl}_{3}$ the low temperature FIR spectrum (Fig. $1 \mathrm{a}$ ) may be considered: The absorption bands at 333 and $189 \mathrm{~cm}^{-1}$ correspond to $\mathrm{SbCl}_{6}^{-}$stretching and deformation frequencies $\left(v_{3}, v_{4}\left(\mathrm{~F}_{1 \mathrm{u}}\right)\right)$.

The great instability of $\mathrm{Sb}(\mathrm{I})$ compounds [25], whose existence in the condensed state was not proved distinctly until now, should cause a short life time. Possibly this could explain that an expected isomery shift for solid $\mathrm{SbCl}_{3}$ is not found in Mößbauer spectra (Sb(I), Sb(III), Sb(V)) [26].

\section{Acknowledgements}

Thanks are expressed to D. Grünewald for recording Raman spectra and to Dr. M. Somer for the measurement of the low temperature FIR spectrum. Furthermore we gratefully acknowledge financial support from Deutsche Forschungsgemeinschaft (DFG).
[15] P. W. Davis and R. A. Oetjen, J. Mol. Spectrosc. 2, 253 (1958).

[16] H. C. Gaebell, G. Meyer, and R. Hoppe, Z. anorg. allg. Chem. 493, 65 (1982).

[17] D. J. Stufkens and H. Gerding, Rec. Trav. Chim. 89, 1267 (1970).

[18] F. J. Brinkmann, Inorg. Nucl. Chem. Letters 6, 453 and 599 (1970)

[19] I. R. Beattie, T. Gilson, K. Livingston, V. Fawcett, and G. A. Ozin, J. Chem. Soc. (A) 1967, 712.

[20] J. Weidlein, U. Müller, and K. Dehnicke, Schwingungsspektroskopie, Thieme-Verlag, Stuttgart 1982.

[21] T. Barrowcliffe, I. R. Beattie, P. Day, and K. Livingston, J. Chem. Soc. (A) 1967, 1810.

[22] K. Prassides and P. Day, J. Amer. Chem. Soc. 105, 3366 (1983).

[23] K. Prassides and P. Day, J. Chem. Soc., Faraday Trans. 2 81, 1259 (1985).

[24] R. J. H. Clark and W. R. Trumble, J. Chem. Soc. (A) 1976, 1145.

[25] W. J. Balfour and R. S. Ram, J. Mol. Spectrosc. 130, 389 (1988).

[26] L. H. Bowen, J. G. Stevens, and G. G. Long, J. Chem. Phys. 51, 2010 (1969) 